\title{
Corrigendum: THZ1 targeting CDK7 suppresses STAT transcriptional activity and sensitizes T-cell lymphomas to BCL2 inhibitors
}

Florencia Cayrol, Pannee Praditsuktavorn, Tharu M. Fernando, Nicholas Kwiatkowski, Rossella Marullo, M. Nieves Calvo-Vidal, Jude Phillip, Benet Pera, Shao Ning Yang, Kaipol Takpradit, Lidia Roman, Marcello Gaudiano, Ramona Crescenzo, Jia Ruan, Giorgio Inghirami, Tinghu Zhang, Graciela Cremaschi, Nathanael S. Gray \& Leandro Cerchietti

Nature Communications 8:14290 doi: 10.1038/ncomms14290 (2017); Published 30 Jan 2017; Updated 20 Feb 2017

The original version of this Article contained an error in the spelling of the author Rossella Marullo, which was incorrectly given as Rosella Marullo. This has now been corrected in both the PDF and HTML versions of the Article.

(c) (i) This work is licensed under a Creative Commons Attribution 4.0 International License. The images or other third party material in this article are included in the article's Creative Commons license, unless indicated otherwise in the credit line; if the material is not included under the Creative Commons license, users will need to obtain permission from the license holder to reproduce the material. To view a copy of this license, visit http://creativecommons.org/licenses/by/4.0/

(C) The Author(s) 2017 